\title{
12 Uganda and the Intergovernmental Authority on Development (IGAD)
}

\author{
Kasaija Phillip Apuuli
}

\section{Introduction}

Uganda is a founding member of both the Intergovernmental Authority on Drought and Desertification (IGADD) and its successor the Intergovernmental Authority on Development (IGAD). This chapter discusses Uganda's membership of and relations with IGAD. While Uganda has benefitted from the organisation's programmes, such as the Conflict Early Warning and Response Mechanism (CEWARN), and participated in the peace processes in Sudan, Somalia, and South Sudan, in recent years the country has not been enthusiastic about its membership of IGAD. Firstly, IGAD has been absent in finding resolutions to the numerous conflicts that have rocked Uganda especially the Lord's Resistance Amy (LRA) insurgency in the north of the country that lasted more than 20 years. Secondly, Uganda has accumulated arrears in the form of membership fees running to millions of US dollars. Thirdly, Uganda's unilateral intervention in the South Sudan conflict in December 2013 resulted in tensions with other members of the organisation. Fourthly, Uganda has had a cat and mouse relationship with Sudan over accusations that the two countries support rebels in each other's territory, with IGAD not doing much about the arising tensions. Lastly, increasingly Uganda has focused on its membership of other regional economic communities (RECs), in particular the East African Community (EAC). Uganda's stance on IGAD is possibly explained by two reasons: first, President Yoweri Museveni's view that Uganda should not be party to the perennial quarrels between Ethiopia and Eritrea that continue to rock the organisation; and second, that the EAC, which Museveni is rumoured to wish to head when it is finally established, promises more to Uganda in the form of a political federation.

\section{IGAD and Uganda}

\section{The Conflict Early Warning and Response Mechanism (CEWARN)}

As a founding member of IGAD, Uganda has been at the centre of the activities of the organisation. Specifically, IGAD has since 2003 been running the CEWARN project in the Karamoja Cluster. The Karamoja Cluster refers to an area of land that straddles the borders between southwestern Ethiopia, northwestern Kenya, 
southeastern South Sudan, and northeastern Uganda (Aheri, 2010, 2). The area is populated by 15 pastoralist communities who share a common language, culture, and way of life. ${ }^{1}$ The Cluster is defined by the dominant mode of production practised by its people: pastoralism, or the use of rangeland for extensive livestock grazing by semi- or wholly nomadic communities (Bevan, 2008, 20). Rainfall is generally unpredictable and localised, making agriculture an unreliable subsistence strategy (Aheri, 2010, 3). The main economic activity in the Karamoja Cluster is livestock herding and thus conflicts that present in the area are mainly about pastures and water points. The situation in the Cluster is exacerbated by the proliferation of small arms and light weapons (SALW), which are used by the population to protect their livestock and to engage in cattle rustling in other communities. The conflicts are often cross-border, at times planned in one country and executed in another (Aheri, 2010, 3). At other times, the conflicts are also internal to one country, but tension can seep into neighbouring countries. In general, the Karamoja Cluster is a marginalised zone, receiving proportionally less consideration in mainstream development programmes from the states of the region (USAID, 2005, 13). While governments have pursued policies that tend to brutalise and marginalise pastoralists, making pastoralists view state policies with serious misgivings, the pastoralist groups feel that their needs and interests are not adequately addressed in the general planning of national mainstream development (USAID, 2005, 15).

It is within the context of ameliorating the situation in the Karamoja Cluster that CEWARN was designed as a system to cover both early warning and response with regard to conflicts that affect the people living in the Cluster. CEWARN is, among other things, aimed at gathering, verifying, processing, and analysing information about conflicts in the region; and communicating all such information and analyses to the decision-makers of IGAD policy organs and national governments of member states (IGAD, 2002, Article 5 (1)(a-c)). Upon receipt, policymakers are meant to craft responses to the conflicts that are brewing.

Of all the conflict early warning systems that are being developed on the African continent, only CEWARN is building an integrated response mechanism to include elements of mediation at local level (AU, 2010, para. 87). In this regard, it has worked with the Karamoja Development Agency (KDA), which has been succeeed by the Karamoja Integrated Disarmamemnt and Development Programme (KIDDP) (Government of Uganda, n.d.), ${ }^{2}$ the Ministry of Karamoja Affairs, and the Lutheran World Federation and World Vision, among others, to manage conflicts, especially pastoral ones within the Karamoja Cluster.

Over the years, CEWARN has been producing quarterly reports analysing the nature, characteristics, and dynamics of national and cross-border pastoral and related conflicts, through data and analysis in the Karamoja Cluster (CEWARN, 2008a, 2008b). The reports highlight the incidence and outcomes of violence in the Cluster, and outline the driving factors exacerbating and de-escalating conflicts therein. The mechanism uses a set of 52 socio-political indicators for two types of reports: (1) violent incident reports, with indicators on armed clashes, raids, protest demonstrations, and other crimes; and (2) indicators for reports on 
the presence and status of communal relations, civil society activities, economic activities, governance and media, natural disasters, safety and security, and social services (Wulf and Diebel, 2009, 19). The main contributions of the reports are two-fold: first, recommendations to key stakeholders (governments, civil society organisations, and community-based organisations) contribute to mitigating and de-escalating conflicts; and second, they help to build confidence and collaboration among the named stakeholders. Generally, CEWARN reports have provided a good basis for developing intervention options and mechanisms for response (CEWARN, 2006, 20).

The main drawbacks of the mechanism include the fact that it has not yet managed to link its capacity of early warning with an effective mechanism for prevention of conflict or response to mitigate conflicts after they have broken out (CEWARN, 2006, 20). The mechanism lacks a response component or arrangement to avert imminent conflicts. The gap between early warning and early response has been glaringly exposed by the mechanism's operations in the Karamoja Cluster. While the mechanism has excelled at providing timely, constant, and accurate information on cross-border pastoralist conflicts in the Cluster, it has not managed to build response devices such as information-sharing, communication, and cooperation between the various actors concerned. Conflict prevention, as the mechanism has realised, requires much more cooperation and input of stakeholders at the local, national, and regional levels, both in terms of information provision and implementation of responses (CEWARN, 2006, 21).

Also, the mechanism's activities have remained largely unknown, partly due to the remoteness and inaccessibility of the pilot areas (including the Karamoja Cluster). CEWARN has itself acknowledged that "the mechanism remains unknown in the member states, in the region, and most importantly, among the local communities who are supposed to be the direct beneficiaries of the early warning and early response functions" (CEWARN, 2006, 21). In Uganda, for example, the government only became interested in the mechanism after the president's wife became the Minister for Karamoja Affairs (Apuuli, 2013, 18).

\section{IGAD as a mechanism for conflict resolution in Sudan, Somalia, and South Sudan}

The agreement establishing IGAD declares that the organisation's key aim is to "promote peace and stability in the sub-region, and [create] mechanisms for the prevention, management and resolution of inter and intra-state conflicts through dialogue" (IGAD, 1996, Article 7g). To test the efficacy of this mandate, the organisation became a mechanism for resolving conflicts in the member states of Sudan (2002), Somalia (2004), and South Sudan (2014-2015). The agreements reached to end the conflicts respectively have endured, albeit with challenges. These are: the Comprehensive Peace Agreement (CPA) (2005); the Agreement on Somalia Peace and National Reconciliation (2004); and the Agreement to resolve the Conflict in South Sudan (ARCSS) (2015). Uganda has been part of all the IGAD peace processes in the three countries, either as an observer or active 
participant. For example, when IGADD launched its peace initiative for Sudan in Addis Ababa, Ethiopia, in September 1993, it appointed a peace committee comprising the heads of state of Ethiopia, Eritrea, Kenya (the chair), and Uganda (Apuuli, 2011,352). This committee of heads of state guided a mediation committee made up of foreign ministers from the same countries. In the case of Somalia, the IGAD facilitation committee comprising of the special envoys of Djibouti, Eritrea, Kenya, and Uganda performed the day-to-day running of the Somalia National Reconciliation Conference in Nairobi, Kenya (Apuuli, 2011, 357). Later on, when a decision was taken to deploy an African Union (AU) peace support mission to Somalia, Uganda became the initial contributor to the AU Mission in Somalia (AMISOM) in March 2007.

\section{Uganda's unilateral intervention in the South Sudan conflict}

In South Sudan in mid-December 2013, tensions that had been simmering between President Salva Kiir and Vice President Riek Machar broke out into open violence. The fighting pitted factions of the Sudan People's Liberation Movement/ Army (SPLM/A) aligned to the two men. In the immediate aftermath of the outbreak of fighting in Juba, Uganda deployed elements of the army, the Uganda People's Defence Force (UPDF), to secure Juba International Airport to enable foreigners to evacuate from South Sudan. As the conflict escalated, the Ugandan army became sucked into the fighting on the side of the South Sudan government (the Kiir forces). Ugandan troops were gradually increased up to an estimated level of between 2,000 and 5,000 soldiers (IRIN, 2014). ${ }^{3}$ Uganda's military support to the Kiir forces included air support and tanks.

Uganda's strong links with the SPLM/A includes decades of joint military deployments (International Crisis Group, 2014, 22). When the rebel National Resistance Movement/Army (NRM/A) government came to power in Uganda, it faced an insurgency in the north. The remnants of the defeated Ugandan army, who had taken refuge in Sudan, subsequently launched attacks in Uganda from their bases in Sudan. While the NRM/A was able to defeat a number of these militia groups using military and peace talk strategies, including the Uganda People's Democratic Army and the Holy Spirit Movement I and II, the most virulent insurgent group was the LRA led by Joseph Kony, which took root in northern Uganda.

Following the collapse of peace talks between the LRA and the Ugandan government around 1993-1994, the LRA started getting military assistance from the Khartoum government. According to Dunn,

the Sudanese government was instrumental in transforming [the] rag-tag group of rebels [of the LRA] into a coherent, well supplied military force, largely though training, sharing of logistics and the introduction of more powerful and sophisticated weaponry such as land mines and rocket propelled grenades. 
What prompted Khartoum's support of the LRA was the support that the NRM/A government had extended to the SPLM/A. While Omach $(2010,294)$ has noted that the NRM/A government was sympathetic to the SPLA/M, Tripp $(2010,158)$ states that on 29 March 1989, a secret military cooperation agreement was signed between Uganda and Col. John Garang committing Uganda to provide equipment and training to the SPLA, as well as passports for travel abroad. Uganda also committed to providing the SPLA with free passage through the country while conducting its operations.

When the LRA was forced to leave northern Uganda in the mid-2000s, it first relocated to South Sudan and then moved to Garamba National Park in the Democratic Republic of Congo (DRC). Later on, the remnants of the LRA moved to and started operating in the Central African Republic (CAR). Because of the regionalisation of the LRA problem, the AU formally designated the LRA as a terrorist group and authorised the establishment of the Regional Cooperation Initiative for the Elimination of the LRA (RCI-LRA) in November 2011 (AU, 2014). Member countries affected by the LRA, namely Uganda, South Sudan, the DRC, and the CAR, contributing to the RCI-LRA, were authorised to conduct counter-LRA operations to protect the local people. The mandated strength of the RCI-LRA in 2013 was 5,000 troops, with Uganda contributing 2,000, the DRC 500, South Sudan 500, and the CAR 350 (Dersso, 2014, 61). The RCI-RTF was reinforced by United States military advisors.

So when the South Sudan conflict broke out in December 2013, the UPDF was in a position to intervene as a result of long-standing engagements with the SPLA.

\section{Disagreements in IGAD on Uganda's unilateral intervention}

Uganda's military intervention in South Sudan was not welcomed by all IGAD countries. The first IGAD summit that was held in late December 2013 in the aftermath of Uganda's intervention neither authorised nor endorsed Uganda's intervention. The summit "commended Uganda's efforts in securing critical infrastructure and installations in South Sudan and pledge[d] its support to these efforts" (IGAD, 2013, para. 13). When it was officially announced that Ugandan troops were fighting on behalf of South Sudan government forces against the rebels, a spokesperson of Ethiopia's then Prime Minister Hailemariam Desalegn noted that Ugandan troops engaging in combat in South Sudan were "absolutely unwarranted" (The Daily Monitor, 2014, 4-14). Kenya, which was holding the chair of the EAC, also distanced itself from Uganda's intervention, with Cabinet Secretary Phyllis Kandie noting that "Uganda's decision to engage militarily in South Sudan was political and not supported by the EAC" (South Sudan News Agency, 2014).

The intervention also exacerbated already strained relations between Uganda and the Sudan. In 1995, in the wake of failed peace talks between the LRA and the Ugandan government, and amid accusations of supporting dissidents in each other's country, Uganda and Sudan broke off diplomatic relations (Papa, Mapendere, and Dillon, 2010, 350). Subsequently, the NRM/A government intensified its 
support for the SPLA with, at one point, the group sharing military facilities with the Ugandan army (Omach, 2010, 298). In addition, Ugandan troops made periodic incursions into Sudan in pursuit of the LRA and two other Ugandan rebel groups, the West Nile Bank Front and the Uganda National Rescue Front II, and also in support of the SPLA (Omach, 2010, 298).

In 1999, the Sudan-Uganda peace process was initiated, following a request for assistance from the Carter Centre (TCC) by Museveni (Papa et al., 2010, 350). The process resulted in the signing of the December 1999 Nairobi Agreement (Carter Centre, 1999), which resulted in the normalisation of relations between the two countries. In March 2002, the government of Sudan allowed the Ugandan army to pursue the LRA rebels onto its territory in Operation Iron Fist (OIF). In July 2002, the Sudanese president announced his country's forces would actively cooperate in joint military actions with the Ugandan army against the LRA (Feldman, 2008, 48). OIF had the effect of uprooting the LRA from its bases in South Sudan. The signing of the CPA between the SPLA/M and the Sudan government in 2005 did not result in an end to the involvement of Ugandan troops in that part of Sudan. According to LeRiche and Arnold $(2012,204)$, "during the first years of the CPA's interim period, Uganda was allowed to use its army, the UPDF, inside Southern Sudan to conduct counter-insurgency operations against the LRA."

It is against this background that, at the 28th IGAD Extraordinary Summit meeting, Sudan threatened to enter the South Sudan conflict if Uganda did not withdraw from there (Foreign Service officer, 2014). The bad blood between Uganda and Sudan appears to have been precipitated by the presence in Kampala of rebels of the Sudan Revolutionary Front (SRF) who were fighting the Khartoum government. ${ }^{4}$ When President Omar al-Bashir requested Museveni to expel the SRF, Museveni argued that Bashir should first address the rebels' problems so that Uganda would not have any reason to give them sanctuary (Foreign Service officer, 2014).

Relations between Uganda and Sudan were further strained by the presence of rebels opposed to the Khartoum government in South Sudan supported by Uganda. In his report of February 2015 on the conflict in South Sudan to the UN Security Council, the UN Secretary-General pointed out that the regionalisation of the South Sudan conflict had been caused by the presence of a number of non-South Sudanese militia groups in the border areas between Sudan and South Sudan (Western Bahr el-Ghazal, Unity, and Upper Nile States), including cadres belonging to SPLM-North, the Justice and Equality Movement (JEM), and Sudan Liberation Army (SLA) factions (UN Security Council, 2015, para. 23).

In December 2014, the national security director of Sudan had warned that, if required, the government would pursue Sudanese armed groups into South Sudanese territory (UN Security Council, 2015, para. 23). In February 2015, Sudanese Vice President Hasabo Mohammed Abdalla visited Uganda and held talks with President Museveni (New Vision, 2015). Abdalla also met members of parliament of the ruling NRM party and proposed an exchange of visits between them and members of the National Congress Party (NCP), "in order to strengthen 
the African solidarity and cooperation for the good of the people of the continent" (New Vision, 2015). In September 2015, Museveni visited Khartoum and held talks with Bashir (Sudan Tribune, 2015) in the aftermath of the signing of the IGADmediated Agreement for the Resolution of Conflict in South Sudan (ARCSS). Under the terms of the agreement, Ugandan troops withdrew from South Sudan.

On the surface, it appears Uganda has patched up its relations with the other IGAD members in the aftermath of its unilateral military intervention in South Sudan. Even Ethiopia which was initially critical of Uganda's fighting alongside SPLA forces against the rebels appears to have toned down its criticism, with Prime Minister Hailemariam Desalegn making a state visit to Uganda (Uganda Today, 2017).

\section{Uganda's stance towards IGAD}

\section{Conflict in Uganda}

When Museveni took over power in Uganda in January 1986, many rebel groups were established to fight his government. While the government militarily defeated most of them, the LRA became a hard nut to crack. The LRA leader, Joseph Kony, proclaimed himself a messianic prophet and stated that he aimed to overthrow the Museveni regime and rule Uganda according to the biblical Ten Commandments. At no time during the LRA insurgency, which lasted slightly more than 20 years, did IGAD consider intervening to resolve the conflict in northern Uganda. Even when the government of Uganda started peace talks with the LRA in Juba in June 2006, IGAD was nowhere to be seen. The reason for this could be that Uganda argued that it was an internal affair that it had to deal with itself. ${ }^{5}$ But Healy $(2009,12)$ provides an explanation for IGAD's no-show when she observes that the "authoritarian political culture of the regional leaders, militates against organizations [such as IGAD] playing a proactive role in peace and security [issues]."

\section{Membership financial contributions}

Uganda provided the second executive secretary of the IGADD ${ }^{6}$ and a number of Ugandan nationals have been or are currently part of the staff of the organisation. ${ }^{7}$ However, over the years Uganda's financial contribution to IGAD has been dismal. In fact, in the mid-2000s the organisation quietly refused to recruit Ugandan nationals due to the country's non-payment of its membership dues. By the end of 2008, Uganda was one of the member states that had accumulated arrears in membership contributions running to millions of US dollars (Apuuli, 2011, 367). As of 2016, the financial arrears owed by Uganda had accumulated to over USD $\$ 8$ million (Foreign Service officer, 2016). Uganda's failure to pay its membership contributions to IGAD is partly explained by the unofficial stance adopted by Museveni, who argued that the country should concentrate on building the EAC. This point is further explained below. 


\section{Uganda and the East African Community}

The integration of the East Africa region (Kenya, Tanzania, and Uganda) started with the building of the Uganda Railway by British colonialists during the second half of 1890s. In the subsequent years up to 1961, the political economy of the region was integrated, with the establishment of an East African customs union, a common market, a single currency, high commission (comprising the colonial governors then ruling the three territories), and a common services organisation. Following the attainment of independence by the three countries, there was a proposal to establish a federation; but the proposal did not gain traction in Uganda. In 1967, the three countries established the EAC, which unfortunately collapsed in 1977. While still fighting to capture power, Museveni and his NRM/A put the revival of East African integration among the top priorities if they captured power. Indeed, at his swearing-in ceremony in January 1986, Museveni observed:

originally we had an East African market but it was messed up by the Excellences and Honourable ministers. It will be a cardinal point in our programme to ensure that we encourage co-operation in economic matters, especially in transport and communication within the East African region.

(Ugandan Diaspora, 2015)

Indeed, beginning in the early 1990s, Kenya, Tanzania, and Uganda embarked on the revival of the EAC. ${ }^{8}$ The EAC Treaty came into force in 2000. Since then, a number of institutions have been established including the East African Legislative Assembly (EALA), the East African Court of Justice (EACJ), and the East African Community Secretariat. These institutions have been given powers affecting the member states to varying degrees.

Museveni has been at the forefront of arguing for the political integration of the East African countries. In this regard, in a paper titled "Towards a closer cooperation in Africa" (Museveni, 1998), which was published when the draft EAC Treaty was being debated, he made a number of arguments suggesting that the region should deepen its integration into a political federation. First, he argued that economic integration could not take place in a context of political fragmentation. Thus, East African integration could not reach far since there was a lack of political superstructure necessary for the integration process to proceed. Given the present economically weak conditions of the regional countries, Museveni concluded that no single state could impose discipline on the others by economic or other forms of pressure.

Second, a union would command more defence potential to guard African interests against encroachment by foreigners as "the present small African states individually, do not possess much defense capacity” (Museveni 1998).

Thirdly, there were already basic linkages in Africa, in general, and in East Africa, in particular, through languages and culture. With regard to language, Museveni cited the example of the Luo language, which is spoken by Nilotic peoples, who are found in Kenya, Uganda, Sudan Tanzania, and parts of Ethiopia and the DRC. In terms of culture, he argued that Bantu culture straddles East, Central, 
and Southern Africa. He further argued that Africa must create a centre of gravity, just as the United States is a centre of gravity for Anglo-Saxon-Latin civilisation. The countries that would establish the initial vanguard of the union would be Uganda, Kenya, Tanzania, Rwanda, and Burundi, because of the advantage of being geographically contiguous and sharing - to a certain degree - a common language (Swahili) and culture, he argued. Other countries would be encouraged to join, as long as they were geographically contiguous to the union. According to Museveni the union would be that of East and Central African states, with power being shared between the union government and the national governments. While the union government would be responsible for external defence, foreign affairs, common market affairs, common services - such as railways, harbours, and posts and telecommunications - and scientific research, the national governments would share responsibility with districts in the areas of justice, education, health, internal security, roads, wildlife, tourism, and agriculture, among others.

Lastly, a union of Central and Eastern Africa states would command more respect from the world. For example, "an investor would be more attracted to invest in a united East Africa than in just Uganda because of the bigger market the former offers" (Museveni, 1998), he argued.

Since first making the arguments for the integration of the East African region in 1998, Museveni has for the last 20 years been amplifying his vision for the region. In various speeches, and at different fora, he has made the case for deepening the integration of the region. For example, while addressing the 16th COMESA summit meeting in 2012, he observed that "the people of East Africa have, for decades, been yearning for an East African Federation that would deal with both political and economic integration. This is the ultimate goal of EAC" (Museveni, 2012). More recently, Museveni noted that the revival of the EAC had created a bigger market for Ugandan products such as milk (Museveni, 2016). He added that the bigger market had enabled East Africa "to better negotiate for market access to other foreign markets e.g. USA, EU, China, India, Japan, Russia, the Gulf, etc. This is where the future of our prosperity lies" (Museveni, 2016). In summary, Museveni argued that

regional integration, especially for the EAC, is crucial because of our strategic security and survival as a free people [...] The EAC, in its present state, is about the size of India in land area with a population of 160 million people. This is a good nucleus for a very powerful, in global terms, African State that would be the centre of gravity of the African people's destiny as free peoples.

(Museveni, 2016)

Museveni's enthusiasm for an integrated East African region has, however, raised suspicion about his intentions. For example, his 1998 paper referred to above was greeted with consternation at home and in regional capitals. At the time, Ugandan troops were preparing to invade the DRC for the second time, having helped install Laurent Kabila as president following the 1996-1997 civil war in what was then Zaire. In July 2007, Museveni undertook a road trip to Kenya and Tanzania, 
where he awarded medals to then vice president of Kenya Moody Awori, and the first president of Tanzania, the late Mwalimu Julius Nyerere (Gyezaho and Muggaga, 2007; Kalinge-Nnyago, 2007). To some, the road trip was suspicious, and they construed it as the start of his campaign to become federal president of East Africa (Gyezaho and Muggaga, 2007). In its editorial of 15 July 2007, the Daily Nation newspaper of Kenya observed that Museveni's move was being watched with puzzled interest in that country (Daily Nation, 2007).

In the end, the seeming lack of interest in IGAD by Uganda (Museveni) should be seen within the above context. It suffices to note that only the EAC has a clear goal in mind for the end product of its integration (i.e. political federation). In contrast, IGAD has been struggling to even define its minimum integration plan. ${ }^{9}$ Thus, the EAC seems to be more attractive to Uganda (Museveni) than IGAD.

\section{Conclusion}

Over the years, Uganda has exhibited an ambivalent stance towards IGAD. While the organisation afforded Uganda the opportunity to participate in the peace processes in Sudan, Somalia, and South Sudan, it played no role in resolving the long-running insurgency by the LRA in northern Uganda. This could have diminished IGAD's image in the eyes of the Ugandan leadership.

Uganda has in the past fallen behind in paying its membership contributions to IGAD, which resulted in accumulated arrears running into several million US dollars. Uganda's failure to pay is explained firstly by the sentiment expressed by Museveni that the organisation is preoccupied with the Ethiopia-Eritrea quarrels that Uganda should not be part of; and, secondly, Museveni's view that Uganda should concentrate on building the EAC. On the latter point, it is rumoured that Museveni wants an integrated East African region because he wants to lead it.

Lastly, Uganda's unilateral military intervention in the South Sudan conflict divided IGAD as an organisation. The intervention precipitated criticism of Uganda from IGAD members such as Ethiopia and Kenya, while at the same exacerbating already strained relations with Sudan. Following the signing of the ARCSS in 2015, however, it seems IGAD members have patched up their differences.

\section{Notes}

1 They are: the Nyangatom and Merille of Ethiopia; Toposa and Didinga of South Sudan; Pokot and Turkana of Kenya; Jie, Pian, Matheniko, Tepeth, Dodoth, Nyaakwae, Bokora, Labwor, and Pokot of Uganda.

2 The KIDDP harmonises the various development interventions by the government, bilateral and multilateral development partners, and international and national nongovernmental and community-based organisations. It represents an attempt by the government of Uganda to integrate gun collection (disarmament) with development interventions; conflict management; and peace building.

3 Note that there was no official Ugandan government figure for the number of troops the country deployed in South Sudan. 
4 In February 2015, reports started filtering through that Uganda was expelling rebels opposed to the Khartoum government from its territory.

5 See, for example, UN Security Council (2016) detailing the steps the government had taken to end the conflict.

6 Dr David Muduuli was appointed in 1991.

7 This author was a conflict prevention, management, and resolution advisor at the IGAD Secretariat in 2008, and assistant to the IGAD Facilitator for Somalia Peace and National Reconciliation in 2009. Other Ugandan nationals employed by IGAD included: Dr Were, Translator; Juliet Kamara, Programme Manager for Documentation; and Dr Ziiwa, Programme Manager for Agriculture.

8 The membership of the EAC has increased with Burundi and Rwanda being admitted in 2007, and South Sudan in 2016.

9 The author knows this very well, as in 2008 he was asked to write a position paper on the same.

\section{References}

Aheri, J.R. (2010). Livestock conflicts: An analysis of Karamoja cluster communities, Institute of Diplomacy, University of Nairobi. Retrieved July 15, 2016 from https://ww w.academia.edu/1194123/Livestock_Conflicts_An_Analysis_of_Karamoja_Cluster_ Communities.

Apuuli, K.P. (2011). IGAD's peace and security strategy: A panacea for long-term stability in the Horn of Africa region? In Roba Sharamo and Berouk Mesgin (Eds.), Regional security in the post-Cold War Horn of Africa (pp. 347-375). Pretoria: Institute for Security Studies.

Apuuli, K.P. (2013). The intergovernmental authority on development's conflict early warning and response mechanism: Can it go beyond pastoral conflicts? African Security Review, 22(2), 11-25.

AU. (2010). African peace and security architecture (APSA): 2010 assessment study draft report. Addis Ababa: African Union Commission.

AU. (2014). African union handbook 2014. Addis Ababa: African Union Commission.

Bevan, J. (2008). Crisis in Karamoja: Armed violence and the failure of disarmament in Uganda's most deprived region. Geneva: Small Arms Survey.

Carter Center. (1999). Agreement between the Governments of Sudan and Uganda (The Nairobi Agreement). Retrieved April 2, 2014 from http://www.cartercenter.org/do cuments/nondatabase/nairobi\%20agreement\%201999.htm.

CEWARN. (2006). CEWARN strategy 2007-2011. Addis Ababa: CEWARN Unit.

CEWARN. (2008a). 12th regional report on the Karamoja cluster (Ethiopia, Kenya and Uganda). Addis Ababa: CEWARN Unit.

CEWARN. (2008b). 13th regional report on the Karamoja Cluster (Ethiopia, Kenya and Uganda). Addis Ababa: CEWARN Unit.

Daily Nation. (2007, July 15). Kenya: Museveni's latest actions raising eyebrows. Retrieved July 16, 2016 from http://allafrica.com/stories/200707150033.html.

Dersso, S.A. (2014). Annual review of the African Union Peace and Security Council 2013/2014. Addis Ababa: Institute for Security Studies.

Dunn, K.C. (2010). The Lord's Resistance Army and African international relations. African Security, 3(1), 46-63.

Feldman, R.L. (2008). Why Uganda has failed to defeat the Lord's Resistance Army. Defense \& Security Analysis, 24(1), 45-52. 


\section{Kasaija Phillip Apuuli}

Foreign Service Officer. (2014). Interview. Ministry of Foreign Affairs, Kampala, December 11.

Foreign Service Officer. (2016). Interview. Ministry of Foreign Affairs, Kampala, May 30 .

Government of Uganda. (n.d.). Karamoja Integrated Disarmament and Development Programme (KIDDP): A revised sector comprehensive log-frame 2011-2015 (draft). Office of the Prime Minister. Retrieved July 18, 2016 from http:/opm.go.ug/assets/m edia/resources/15/KIDDP.pdf.

Gyezaho, E., and Muggaga, H. (2007). Museveni starts EA road tour. Daily Monitor. September 25, 2007. Retrieved July 16, 2016 from http://www.monitor.co.ug/News/ Education/-/688336/783218/-/item/1/-/q3ulc1/-/index.html.

Healy, S. (2009). Peacemaking in the midst of war: An assessment of IGAD's contribution to regional security in the Horn of Africa (Crisis States Working Paper no. 59). London: London School of Economics. Retrieved July 29, 2016 from http://eprints.lse.ac.uk/ 28482/1/WP59.2.pdf.

IGAD. (1996). Agreement establishing the inter-governmental authority on development, assembly of heads of state and government. Nairobi: IGAD/SUM/AGRE-DOC.

IGAD. (2002). Protocol on the establishment of a conflict early warning and response mechanism for IGAD members states. Retrieved July 15, 2016 from http://www.iss.co .za/af/regorg/unity_to_union/pdfs/igad/Protocol.pdf.

IGAD. (2013). Communique of the 23rd extra-ordinary session of the IGAD assembly of heads of state and government on the situation in South Sudan. Nairobi, Kenya, December 27. Retrieved April 12, 2017 from http://igad.int/attachments/725_23rd_Ext ra_Summit.pdf.

International Crisis Group (ICG). (2014). South Sudan: A civil war by any other name (Africa Report no. 217). Addis Ababa: ICG.

IRIN. (2014, February 13). South Sudan crisis ripples across region. Retrieved March 30, 2014 from http://reliefweb.int/report/south-sudan/south-sudan-s-crisis-ripples-a cross-region.

Kalinge-Nnyago, O.D. (2007, July 15). Uganda: Museveni steals the limelight on his East African roadshow. The New Times. Retrieved July 16, 2016 from http://allafrica.com/ stories/200707160980.html.

LeRiche, M., and Arnold, M. (2012). South Sudan: From revolution to independence. London: C. Hurst \& Company Ltd.

Museveni, Y.K. (1998). Towards a closer cooperation in Africa, Kampala, paper delivered by Museveni to his NRM party in July 1998, unpublished (on file with the author).

Museveni, Y.K. (2012). Speech at the 16th COMESA Summit. Speke Resort, Munyonyo, November 23. Retrieved July 15, 2016 from http://www.statehouse.go.ug/media/s peeches/2012/11/24/speech-he-yoweri-kaguta-museveni-president-republic-uganda -16th-comesa-sum.

Museveni, Y.K. (2016). Geo-politics, regional integration and national interests. Speech given at Kyankwanzi, March 15. Retrieved July 18, 2016 from http://www.statehouse .go.ug/media/speeches/2016/03/15/geo-politics-regional-integration-and-national-inte rests.

New Vision. (2015, February 10). Sudanese vice-president hails NRM MPs. Retrieved April 12, 2016 from http://www.newvision.co.ug/new:vision/news/1320503/sudanesevice-president-hails-nrm-mps.

Omach, P. (2010). The regionalization of rebel activities: The case of the Lord's Resistance Army. In Wafula Okumu and Augustine Ikelegbe (Eds.), Militias, rebels and militants: 
Human insecurity and state crises in Africa (pp. 287-311). Pretoria: Institute for Security Studies.

Papa, M.J., Mapendere, J., and Dillon, P.J. (2010). Waging peace through improvisational action: Track-two diplomacy in the Sudan-Uganda conflict. Southern Communication Journal, 75(4), 349-369.

South Sudan News Agency. (2014, January 22). EAC disowns Uganda's military intervention in South Sudan. Retrieved April 12, 2017 from http://allafrica.com/stories /201401220157.html.

Sudan Tribune. (2015, September 15). Bashir and Museveni discuss bilateral ties, peace in South Sudan. Retrieved April 12, 2017 from http://www.sudantribune.com/spip.ph p?article56403.

The Daily Monitor (2014, January). Uganda leader says helping South Sudan fight rebels (pp. 4, 14).

Tripp, M. (2010). Museveni's Uganda: Paradoxes of power in a hybrid regime. London: Lynne Rienner Publishers.

Uganda Today. (2017, March 2). Ethiopia Prime Minister Desalegn in Uganda on Threeday state visit. Retrieved April 12, 2017 from http://www.theugandatoday.com/educa tion/2017/03/ethiopia-prime-minister-desalegn-in-uganda-on-three-day-state-visit/.

Ugandan Diaspora. (2015, January 26). Liberation Day 1986/Revisiting President Museveni's inaugural fundamental change speech 29 years later! Retrieved July 18, 2016 from http://www.ugandandiasporanews.com/2015/01/26/liberation-day-revisitin g-president-musevenis-inaugural-fundamental-change-speech-29-years-later/.

UN Security Council. (2016). Letter dated January 16 from the Chargé d'affaires of the Permanent Mission of Uganda to the United Nations addressed to the President of the Security Council (S/2006/29).

United Nations Security Council (UNSC). (2015). Report of the Secretary-General on South Sudan (covering the period from 18 November 2014-10 February 2015) (S/2015/118).

USAID. (2005). Conflict Early warning and mitigation of resource based conflicts in the greater Horn of Africa: Conflict baseline study report conducted in the Karamajong Cluster of Kenya and Uganda.

Wulf, H., and Diebel, T. (2009). Conflict early warning and response mechanism: Tools for enhancing the effectiveness of regional organizations? A comparative study of the $A U, E C O W A S, I G A D, A S E A N / A R F$ and PIF (Crisis States Working Papers Series no. 2). Institute für Entwicklung und Frieden. 